\title{
Physiosemiosis in the semiotic spiral: A play of musement ${ }^{1}$
}

\author{
John Deely \\ University of St. Thomas, 3800 Montrose Boulevard, \\ Houston, Texas 77006, USA \\ e-mail: deelyj@stthom.edu
}

\begin{abstract}
A main question for semiotics today is how far does the paradigm for the action of signs, semiosis, extend. There is general agreement by now that semiosis extends at least as far as awareness or cognition occurs, which includes the entire domain of animal sign usage, or zoosemiosis. The open question today is whether semiotics is broader still, and on this question two positions have emerged. The comparatively conservative position would extend semiotics to the whole of living things. This extension was first formally proposed and argued under the label phytosemiotics, the study of an action of signs in the realm of vegetable life. The conservative faction has rallied around the label of biosemiotics. The more radical faction argues that even this extension leaves something out, namely, the physical universe at large which surrounds and upon which depends all life. The radical argument is that what is distinctive of the action of signs is the shaping of the past on the basis of future events, a shaping that can be discerned even in the rocks and among the stars - a veritable physiosemiosis, theoretical justification and practical exploration of which marks the final frontier of semiotic inquiry.
\end{abstract}

It may well be that nothing has so retarded the contemporary development of semiotic consciousness as has Peirce's erroneous identification of the causality proper to sign with the old "final causality" of Aristotle, despite Peirce's juxtaposition of this term with the more accurate expression "ideal cause", 2 which, however, still misses the

\footnotetext{
1 "Musement" here is used in the sense outlined by Peirce 1908: 452-465.

${ }^{2}$ Peirce c. 1902: CP 1.211: "The signification of the phrase 'final cause' must be determined by its use in the statement of Aristotle [here the editors insert a footnote which, upon pursuit, proves useless] that all causation divides into two grand branches,
} 
exact mark, though it has the advantage at least of being, so to speak, in the right ballpark. ${ }^{3}$ Well, it is a question of time. For this particular failure on Peirce's part is but a vestige of that distinctively Cartesian heritage in philosophy which Peirce, singularly among the moderns, strove mightily to overcome. And even though the Peirceans themselves have in the main so far resisted the radically postmodern historical consciousness that Peirce embodied explicitly in his "ethics of terminology" and practically in his own person and the rest of his work, it can only be a matter of time till the foundational facts of our semiotic heritage emerge into more general consciousness. Once there, they will coerce those in whose awareness they lie unearthed to settle upon the causality truly proper to signs in order to understand their action and the consequences of action predicated upon that causality.

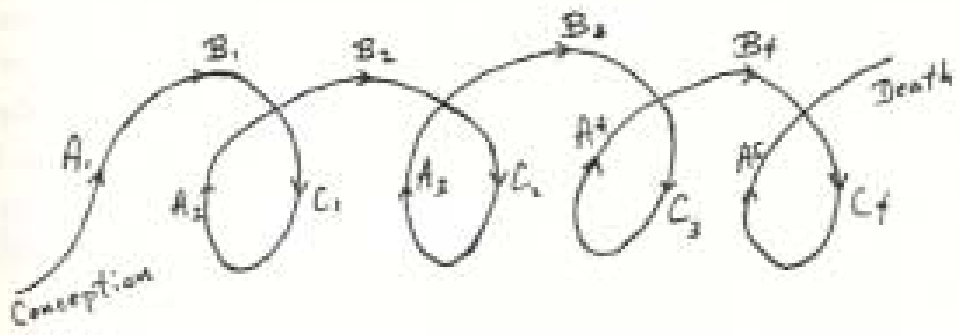

Figure 1. A = "abduction"; B = "deduction"; C = "induction".

Aristotle himself, can I safely say, did not speak of "ideal causality". If Krempel can be trusted, ${ }^{4}$ and he often can in historical if not phi-

the efficient, or forceful; and the ideal, or final. If we are to conserve the truth of that statement, we must understand by final causation that mode of bringing facts about according to which a general description of result is made to come about, quite irrespective of any compulsion for it to come about in this or that particular way; although the means may be adapted to the end. The general result may be brought about at one time in one way, and at another time in another way. Final causation does not determine in what particular way it is to be brought about, but only that the result shall have a certain general character."

${ }^{3}$ Discussion with references in Deely 1994b: 157-172, esp. 158n5 for the Latin background. See, in Deely 2001b, the Index entries: causality; cause, in Latin thought; and esp. objective causality.

${ }^{4}$ Krempel 1952, contextualized semiotically in Deely 2001b: 229-230, 230n50. 
losophical matters, the context for understanding such a causality probably did not exist before Simplicius on the Greek side and Avicenna on the Arabic and Latin side drew the distinctions which make possible the full contrast in principle between objective and physical being, with the consequences for our understanding of the original philosophical notion of "reality" that this contrast entails. In any event, despite his serious pokings about in the ashes of late Latin scholasticism and the foundations of explicitly semiotic consciousness that he found there and incorporated creatively into his own seminally postmodern establishment of semiotics, the full character of "ideal cause" among the Latins as a subordinate subspecies of extrinsic formal cause eluded Peirce's voyages of discovery. ${ }^{5}$ Nonetheless, we know now, or at least are in a position to say, that extrinsic formal cause, in contrast with intrinsic formal cause, is as such not part of the make-up of subjectivity, and hence indirectly at most tied to the doctrine of substance from which the original doctrine of final causality ("teleonomy", as I expect to become the new standard expression for what was central to Aristotle's original notion; see Deely 2001b: 6566) is hardly separable.

The "formal cause" of a thing in the Aristotelian original scheme expressed the subjective coherence or structure which enabled one thing in particular to exist and to be recognized as existing as a particular thing or part of the physical universe as a whole, the "world of Secondness", in Peirce's terms. But existence in the order of Secondness, clearly, is prior to and more fundamental than being recognized as so existing, and so the original notion of "formal cause" was precisely that interior or subjective "glue" according to which one thing — anything — succeeded for a time in maintaining its identity, recognized or not. One and the same formal cause now considered as giving and maintaining the identity of a thing is an intrinsic formal cause, and now considered as enabling and specifying the correct objective recognition of the thing in question by another is an extrinsic formal cause serving as pattern and terminus for a relation of cognition based in (provenating from) an idea (or icon) formed within the subjectivity of the knower.

Extrinsic formal cause the late Latins identified under two guises. One, guiding the artist or builder in his or her work, they called an "idea", or, as we should say, a "blueprint" or "model" on the basis of and after which constructive work should go forward in realizing an

${ }^{5}$ See Beuchot \& Deely 1995; Deely 1995. 
embodiment in the world and order of things which would be the idea fully realized. But another, more fundamental realization of extrinsic formal cause was the notion of formal cause as specifying or controlling awareness to perceive (sensorially or intellectually, it makes no difference to the point) this rather than that. And I think it may already be clear from this juxtaposition that formal cause as specifying is prior to and more fundamental than formal cause as exemplar, even though later exemplars may be original or creative in specifying the awareness of an organism according to an objective world species-specific and never wholly reducible to the physical environment in its speciesindifferent being. ${ }^{6}$

Now such a notion of formal cause, as extrinsic, means: extrinsic to the subjectivity of a knower, something specifying or guiding the awareness of some organism to be aware of one objective "reality" rather than another. The objective reality in question might have a subjective being, in which case the extrinsic formal cause would be embodied in some real object - let us say (by way of example), prey as food. But it might not have a truly corresponding subjective being, as when Ponce de Leon searched the Americas for the Fountain of Youth. It was not that he did not know what he was looking for, just that what he was looking for was not there to be found in the manner he believed it to be, namely, physically as well as objectively.

Even in such cases of delusion or error, the formal cause guiding and specifying our awareness, determining its content from without, does so without resorption into subjectivity; for the subjective idea as founding a suprasubjective relation always remains virtually and in principle distinct from and opposed (correlatively) to the terminus as such of the relation, ${ }^{7}$ and every object as such exists precisely as and at the terminus of some relation of awareness linking it to but transcending the subjectivity of the knower, and indifferent to that knower's situation respecting "truth" or "error".

So we may correct Peirce as our modern master and postmodern guide, and yet say with him that we must understand the causality proper to signs (even though it is a blunder to call this "final causation" $"$ ) as "that mode of bringing facts about according to which a

\footnotetext{
${ }^{6}$ See, in Poinsot 1632, Appendix C, 379/15-382/26, esp. 381/34ff.
}

${ }^{7}$ Poinsot, loc. cit.

${ }^{8}$ A sin against the ethics of terminology, as Peirce would be first to point out once the relevant elements of historical discourse became uncovered. See the statement of 
general description of result is made to come about, quite irrespective of any compulsion for it to come about in this or that particular way; although the means may be adapted to the end. The general result may be brought about at one time in one way, and at another time in another way", 9 as long as the general character of the result is preserved.

Now wherever a "general character" of some event or situation is at issue, we are in the order of relations, and relations in just that sense that modernity followed nominalism in denying: relations as able to exist independently of the activity of the human mind, or any finite mind, for that matter. So relations too belong to the order of Secondness, even though they have that singularly indirect quality so familiar to the Latins, singled out by Poinsot as among the indispensable preliminaries to the doctrine of signs, ${ }^{10}$ of being able to be effected or affected only indirectly by changes introduced into the subjectivity upon which the relation or relations in question find their foundation, from which they take provenance. These relations in the order of Secondness as such are always of a dyadic character, in Peirce's terms, no matter how many termini they may have. For example, a father whose offspring has died is no longer a father, while a father whose direct and living offspring are many is still but one father (to borrow the intriguing example cited by Thomas Aquinas ${ }^{11}$ ). For what makes a relation of Secondness real is precisely that both its "terms", that is to say, both its subjective foundation or basis and its terminus, have the being proper to physical realities as being what they are independent of the awareness enjoyed by or wanting to any finite mind.

But when we move from the universe of Secondness into the universe of Thirdness we do not leave all "real" relations behind, any more than we bring all real relations into our awareness. No. What happens is that we discover that many of the relations we dreamed of under the rubric of Firstness are only that, pure dreams, unrealities compared to what Secondness contains, and yet endowed with their own power and ambiguity in the realm of Thirdness. Here, many an unreal relation functions through its objective reality to signify and to

the "rules themselves" in Peirce 1903; commentary in Ketner 1981, with commentary and extended application in Deely 1998a and 1994a.

${ }^{9}$ Peirce c.1902: CP 1.211.

${ }^{10}$ Poinsot 1632: Second Preamble, Article 1, 88/8-27, esp. 18-26, \& 89/13-20; 95/18-45.

${ }^{11}$ Aquinas c. 1266/73: III, q. 3, art. 5; c.1269/72: Q. 1, art. 2, \& Q. 9, art. 4. Poinsot comments on this point in detail in his Treatise on Signs; see Poinsot 1632: Appendix C, 384/34-387/25. 


\section{John Deely}

affect behavior without by any means its physical unreality in Secondness being operative. If today we no longer burn witches, it is not that our ancestors succeeded in getting them all so much as it is a seachange in socially permissible beliefs upon which the law is deemed able to act.

But here too many a real relation of Secondness, dyadic in its own order as physical, acquires a tercerity under which it becomes able to signify. Thus, to stick to examples common across the ages, smoke is an effect of burning, and as such a real and dyadic relation. But in experience this dyadic character of smoke as effect acquires a further quality it does not have apart from experience, namely, the character of transforming smoke as a mere effect into smoke - as we loosely if not carelessly say — a "sign" of burning, a "sign of fire". A sign of something burning is different from a flag as sign of country, in that our experience testifies as loudly as critical consciousness ever allows experience to testify that the relation between flag and country "depends upon us" in just that way that the relation between smoke and burning does not "depend upon us" but upon the being of something physical or real independently of us (even though mayhap not so independent of us that we might not, say, "put the fire out" etc.). So "relations of Thirdness" constitute the being of the universe of signs, regardless of whether they owe their whole origin to Firstness or to Secondness as well, that is to say, regardless of whether they are, as triadic relations, in whole or in part "real" or "unreal" in the scholastic sense deemed by Peirce of the essence of Pragmaticism (as incompatible with Nominalism in every guise) and distinguishing Pragmaticism as a species of thought from all varieties of Pragmatism as such.

Now one of the annoying traits of Peirce scholarship so far, in clinging to the a-historical trappings of modernity against the counsel and example of their guide in semiotic matters, is the effective maintenance of the "as if" pretense that the discovery was original with Peirce that signs consist in triadic relations. Far from it. We now know that this was the principal element - the notion of sign as a triadic relation - which Peirce acquired from his reading of later Latins that enabled him not merely to pick up the development where they had left it by the 17 th century, but, more decisively, to advance the state of semiotic consciousness. He shifted the focus from the being unique to sign to the action consequent thereon, an action wherein the three elements essential to signification are able to trade places in a spiral of growing consciousness wherein, ideally, each "sign" makes us aware not merely of something other than itself but of something more than 
we were previously aware of, ${ }^{12}$ and becomes in its turn an object generating a new interpretant requiring yet a further sign, and so on, as Peirce says, ad infinitum, at least from the standpoint of finite consciousness.

Yet while it was far from original with Peirce to realize that a sign strictly is not a representation but a triadic relation within which some representation is made to something other both than itself and than the object it represents, it was the privilege of Peirce to assign names to these three "terms" united in the relation constituting the being proper to sign: the term represented he called the significate ${ }^{13}$ or, more usually, the object (so that "object" and "object signified" come to the same thing, a decisive and far-reaching if so far little noticed consequence of semiotic analysis); the term representing he called the representamen; ${ }^{14}$ and the term "represented to" he called the interpretant.

Mats Bergman of the University of Helsinki, with its third incarnation of the "Metaphysical Club", occasioned in a seminar with me in the Fall 2000 semester to investigate Peirce's derivation of this notion of the interpretant as the third term essentially united with representamen and object signified in the being proper to sign. Bergman's approach to the matter followed in essence the principle of historical layering embodied in the Semiotic Society of America Style Sheet, ${ }^{15}$ that is to say, he conformed his discussion of the sources to the actual sequence of dates according to which they came into existence within the lifetime of their author, in this case, Peirce himself. And what he discovered was of the greatest interest theoretically.

To begin with, he found that Peirce's introduction of the term "interpretant" anteceded even the "New List" of 1867, and initially repeated, if only nominalistically, the medieval confusion of the interpretant with some interpreter, or "subject", as Peirce actually termed the notion upon its first introduction in 1865; for the careful reader

12 The point first caught my attention in reading Eco 1990: 28, in his critical distinction between "Hermetic Drift" (to which "deconstruction" tends but need not lead if pursued with sufficient historical insight - normally lacking among late moderns, nonetheless) and semiosis which is not degenerate. It is a point well-made, explicit in Peirce 1904: 8.332, and set in the lintel to the semiotic of John Poinsot (1632: Book I, Question 1, pars. $2 \& 3,116 / 14-117 / 17)$. See further Deely 2001b: 468, 471-2.

${ }^{13}$ Peirce 1905-6: CP 5.488n1.

${ }^{14}$ And here I will not enter again into the reasons why the pronunciation of this term common among the Peirceans, "represent-a-men" is incorrect, "represen-tamen" being the correct distribution of emphasis among syllables.

${ }^{15}$ In The American Journal of Semiotics 4(3/4), 1986, 193-215. 


\section{John Deely}

cannot fail to notice that even upon this first introduction of the term Peirce speaks of the Interpretant ${ }^{16}$ "rather abstracting from the personal element". Further, Bergman found that, in this original context of introduction, Peirce was already onto the fact that the Universe of Thirdness is through and through of the character of representation but that this character yet cannot be assimilated to idealism, as a consequence of the fact that the character of representation is not peculiar to mind but rather to objects as such. And here the sophisticated student of semiotics cannot but advert to the fundamental distinction between things as such in the order of Secondness existing independent of whatever relation they may have or not have with finite awareness, and things as objects - that is to say, things which have entered into determinate relations with cognizing organisms, whence they exist themselves as cognized or known within the texture of an objective world, an Umwelt (Deely 2001a).

In the universe of Thirdness, then, whatever is is representation, but self-representation ("ground") makes of things aspectually also objects, while other-representation makes signs not only of some objects respecting other objects but also of ideas and feelings as presenting objects within experience whether veridically or mistakenly insofar as Secondness is incorporated within Thirdness. In Bergman's own summary:

His view, of course, is that things can be known, precisely as they are involved in representative relations. The idea of an object only arises within representation. Further, Peirce notes that the tendency to associate representation with mind (understood here as our mind) is on the wrong track altogether, as is shown by such examples as Aztec inscriptions that no one can read, or a natural formation on a rock resembling a face no one has seen or shall see. ${ }^{17}$ According to Peirce, such instances are representations, whether they are actually comprehended by human beings or not. Using later terminology, what we have in such cases are signs without human interpreters. (Bergman 2000: $3-4)$

Here we need to exercise the utmost care, and place now squarely before our minds Peirce's distinction (another decisive heritage of late Latin scholastic semiotics definitively established in if not before Poinsot's Treatise on Signs of 1632) between "signs" strictly and loosely speaking. This is a distinction the importance of which has yet

\footnotetext{
${ }^{16}$ Peirce 1865: W 1.327.

${ }^{17}$ Peirce 1865: W 1.326.
} 
far from generally sunk in. ${ }^{18}$ Strictly speaking, nothing that can be seen, heard, or pointed to is a sign according to its proper being! Strictly speaking, nothing that we commonly call "signs", as in "look for the sign for Exit 14", or "There's a sign for the barber shop" are in fact signs strictly speaking. When Maritain said ${ }^{19}$ that animals other than human make use of signs but they do not know that there are signs, his utterance may have been more profound than he realized at the time.

For signs, we now know, consist strictly speaking in triadic relations as such, and triadic relations share one property in common with all relations, including pure dyadic relations in Secondness: they are directly inaccessible to sensation. We can perceive by sense related objects, but their relation prescissed in its proper being is an "object" only for understanding in its difference from perception. Relation apart from related things can be thought and understood intellectually, but it cannot be perceived. Thus, when we "see a stop sign", what we see in fact is a physical object that performs a definite function of representation within our objective world as constituted by customs and laws. The same red octagon attached securely to a post planted firmly in the ground would not be a stop sign for a cognitive organism unfamiliar with the habit structure constitutive of our objective world. Nor would it be a stop sign even for us were it not functioning as an item, one of three, bound up in an itself invisible relationship which is actually the sign strictly speaking. Or, if we prefer a more graphic metaphor to make the point, the visible red octagonal thing is "the mere body of the Sign, which is not essentially such", in contrast with the invisible triadic relation which is "so to speak, the Sign's Soul, which has its Being in its power of serving as intermediary between its Object and a Mind".

${ }^{18}$ In Deely 2001b, see the Index entries for definition of sign, sign, and signvehicle

${ }^{19}$ Maritain 1957. The point is thematized and expanded systematically in Deely 2000a.

${ }^{20}$ Peirce 1908: CP 6.455. In other words, sign loosely so called is technically and strictly a representamen, and what makes any item a representamen rather than a mere thing, say, or rather (or more) than an object signified, or rather than an interpretant, is not any intrinsic quality but its position or role within a triadic relation wherein it serves to stand for another by representing it to yet another again, actual or virtual (as we will see). Over time, changing contexts occasion shifts within the relation, whereby what one time occupied the foreground in representing (the representamen) moves rather to the background as Interpretant, or to the foreground of what is represented as Object, and so on. 
Now, I think, we begin to perceive the true proportions of the problem at hand. Once the sign in its proper being has been intellectually distinguished from the prospectively sense perceptible component parts which, if they are "real", can be and be perceived even outside of and apart from a given sign-relation, but which cannot significantly function unless they are at least perceived within such a relation (so a conspirator, for example, can be falsely perceived, i.e., mistakenly identified, by being mind-dependently made an element in a triadic relation to which mind-independently he does not in fact belong), we are in a position to consider the action of signs in terms of the radical ground of its prior possibility in the being proper to relation.

Just here the ancient Greek discussion of relation, substantially begun by Aristotle in his pioneering attempt to draft a list of categories applicable to Secondness in its proper being, finds its bearing on the doctrine of signs. This is the case, even though, as we now know (thanks mainly to Eco and his collaborators ${ }^{21}$ ), in the ancient world of Greek philosophy there was no notion of "sign in general" such as Augustine introduced in anticipating the debate over nominalism and as Poinsot first vindicated in his demonstration that, even though the notion of relation was properly identified with a mode of real being, this notion yet stood apart as unique in Aristotle's list of categories in being irreducible to the order of mind-independent being. ${ }^{22}$ Real, that is to say, physical, relations depend upon a foundation in subjective being and a terminus which also has the further status of subjectivity. But one and the same relation which was once physical can later be reconstituted objectively in thought despite the nonexistence of its terminus (the pure objectivity there of ${ }^{23}$ ) here and now. Such is the case with the bone of a dinosaur recognized as such. The bone provides the extrinsic formal cause guiding the mind of the paleontologist to form an objective relation terminating in the being of a dinosaur which, here and now, has no physical existence. Similarly, a purely objective relation or set of relations can be made to exist in the physical environment by a manipulation of the subjectively existing physical things here and now present. An irrigation system dreamed up in Firstness can be embodied in Secondness guided by Thirdness.

To see the point of all this for such a notion as that of physiosemiosis, that is, for understanding the possibility of an action of signs

\footnotetext{
${ }^{21}$ E.g., Eco et al. 1986.

${ }^{22}$ See Poinsot 1632: Second Preamble, Article 2, 95/18-96/36.

${ }^{23}$ See Deely 1975.
} 
that over-runs the boundaries of any sort of finite consciousness and even the boundaries of phytosemiosis (the living world as including organisms which we have little reason to consider as cognitive beings), we need to follow Peirce in the manner in which, around 1895, he brings the notion of interpretant out of what Bergman calls hibernation:

Peirce begins to emphasise the directionality of the activity of the sign, as proceeding from the object toward the interpretant. In effect, this means that semiosis is now understood as a process, in which interpretants are in some sense engendered through the mediating function of the sign. As open toward the future, this point of view differs from the position of the 'New List', where the unity of the proposition marked an end-state. In the new conception, there is an endless progression of thought-signs, acting variously in the roles of interpretant and sign. (Bergman 2000: 9-10)

In other words, having stabilized with a marked terminology the three elements or factors brought together whenever the sign achieves the being proper to itself, Peirce now begins to take seriously the shift implicit in this gain. He begins to develop the actual structure of the semiotic spiral which results from the instability of the subjective factors involved in signification depending, as they do, on a temporary occupation of a position or role within a relation which as such is indifferent to the subjectivity of its source vis-à-vis the order of objective being, the Umwelt. And he seems clearly to see that the situation requires a clarification of the fact that the root of the possibility of the Universe of Thirdness finds its original hold in the Universe of Secondess precisely in that insouciance toward mind which characterizes the being of Secondness in contrast no less to the being of the Universe of Firstness than to that of the Universe of Thirdness. For no matter where he turns, Peirce as semiotician finds himself confronted with the irreducible being of relation as suprasubjective and indifferent to provenating from nature or from mind, separately or together, and in whatever sequence of realization. The spiral of semiosis is not only the trajectory of life as marked by experiences. It begins now to appear as the trajectory of the very universe itself as giving birth to life in the first place, the future's way of taking account of and giving shape to the past.

"Let the Muser", Peirce counsels, ${ }^{24}$ "after well appreciating, in its breadth and depth, the unspeakable variety of each Universe, turn to those phenomena that are of the nature of homogeneities of connect-

\footnotetext{
${ }^{24}$ Peirce 1908: CP 6.464.
} 
edness in each; and what a spectacle will unroll itself!". Yet these spectacles of musement within each universe, if the muser recovers enough from the stupendous spectacle to muse yet further on still, will find a semiotic universe to which Firstness, Secondness, and Thirdness all three, mayhap separated by analysis or in imaginary musings, together contribute in the actions consequent upon the being proper to signs. Thirdness, after all, proves not a universe apart from but inclusive of all that Secondness may contain and Firstness may dream, according to the saying of the Latins, anima humana quodammodo omnia est:

From speculations on the homogeneities of each Universe, the Muser will naturally pass to the consideration of homogeneities and connections between two different Universes, or all three. Especially in them all we find one type of occurrence, that of growth, itself consisting in the homogeneities of small parts. This is evident in the growth of motion into displacement, and the growth of force into motion. In growth, too, we find that the three Universes conspire; and a universal feature of it is provision for later stages in earlier ones.

Peirce sees in this path a "humble argument" toward the existence of God. For my part, I see in it more immediately an argument for an action of signs in nature prior to advent of life, for which I have suggested the term "physiosemiosis". I have begun to suspect - it is only a musement - that semiosis may be the proper name for what we have heretofore studied under the rubric of "evolution". For while evolution designates the development of the universe from simpler to more complex arrangements and states, this has always been from the point of view of the present state of the world as determined by past developments. The idea of the past as shaping the present in leading up to it is the essential idea of evolution.

In semiosis there is a question of something richer, something much more complex than the essence of that idea. There is a question, indeed, of the future as shaper of the past, according to the saying of Peirce: $^{25}$ "The existence of thought now depends on what is to be hereafter; so that it has only a potential existence, dependent on the future thought of the community". Within the context of evolution, the "anthropic principle" has been advanced in recent years as a way of inferring from our existence to something about the process or processes of cosmic evolution. But indeed a semiosis at work throughout

\footnotetext{
${ }^{25}$ Peirce 1868: CP 5.316.
} 
the whole of nature, and not just in the biosphere, would achieve the same thing with much greater illuminative power.

To see what I am trying to get at, let me call to your attention Peirce's own moves when he resumes, in the early 1900s, the idea of interpretant introduced a quarter century or more earlier. The original conception was in the context of the third of the three elements united in the being of sign as a triadic relation. The resumption looks rather to the action of signs as determining the position of a given element within the triad of significance, the semiotic triangle. The triangular being of a sign is now set in motion as a spiral of semiosis: getting an idea in the first place (abduction), which is then developed as to its consequences (deduction), and finally tested against experience (induction or "retroduction"), is now seen as resulting in yet a further abduction requiring further deductions and tests leading to further abductions ... and so on, ad infinitum, until death. The spiral, for the individual organism endowed with cognitive capacity, begins at or near conception (far nearer to conception than to birth) and ends at death. But now this metaphor of the spiral of semiosis is recast as model applying to the whole of reality, the very physical universe itself as the cradle of Firstness and Thirdness alike.

Watch the move. "Around the year 1904", Bergman (2000: 10) discovers, "Peirce begins to expand on his conception of the interpretant", and to introduce distinction of varieties thereof, including varieties that are not mental, which raises the possibility "that there might be representamens without mental interpretants - that is, that are not signs in the full sense of his definition". ${ }^{26}$ In particular,

Peirce explicitly notes that the interpretant need not actually exist to guarantee the reality of the sign; a being in futuro suffices. This is a central doctrine of the earliest semeiotic, which appears to have been temporarily ignored in the propositional analysis of the 'New List'. But a more radical change of outlook seems to be required by the path Peirce is pursuing; namely, the identification of various kinds of interpretants, some of which are not signs, cannot proceed comfortably on the basis of a sign-definition in which the interpretant is plainly characterised as a sign. Therefore, it is not surprising that Peirce once more redefines the interpretant; and this time in a far more general and suggestive way than before.

As objects give rise to repraesentamina, Peirce considers, so representamens - which, remember, correspond to the casual and "loose" or common notion of sign - give rise to interpretants respecting their

${ }^{26}$ E.g., Peirce 1903: EP 2.273. 
objects, completing the triadic relation or "semiotic triangle" in which the being of sign properly and strictly consists. So the interpretant, in closing the semiotic triangle, may be regarded as the "effect", the "proper significate outcome", of signs in the sense of representamina. The move seems simple, but the consequences are far-reaching:

Three things should be noted at this point. The first is that this new conception of the interpretant as the proper significate effect of the sign leaves room for interpretants that are not signs, at least not in their primary function as interpretants. ... Secondly, this conception of the interpretant as effect is easier to generalise to various kinds of sign-processes, such as those we find in living nature, than the earlier definition, in which the interpretant was basically understood as a sign. The new approach almost automatically avoids the mentalistic undercurrent, which Peirce never quite managed to eradicate from the earlier position, while still having more substantial implications than his most formal definitions of the sign-relation. ... Thirdly, the communicative derivation leads to a dynamic, processual notion of the sign and its correlates, one which is not boxed up in the unity of the proposition. Peirce now emphasises that the object is in a relevant semiotic sense past in relation to the sign, while the interpretant in general implies a reference to the future ${ }^{27} \ldots$ a significant directionality. (Bergman 2000: 12)

It is a matter of "critical commonsensism". ${ }^{28}$ So naturally "at this point a trained mind will demand that an examination be made of the truth of the interpretation; and the first step in such examination must be a logical analysis of the theory." Luckily, "logical analysis can be put to its full efficiency in Musement", ${ }^{30}$ even though "strict examination would be a task a little too serious for the Musement of hour fractions, and if it is postponed there will be ample remuneration even in the suggestions that there is not time to examine; especially since a few of them" - such as the present one, the suggestion that a semiosis is possible even in the formation of rocks and stars, even in the earliest moments of a "big bang" — "will appeal to reason as all but certain".

Look at the strategy, as Bergman reconstructs it:

Peirce's strategy here is to set out from a common-sense idea of what we mean by 'sign', from which he moves on to extend the term to phenomena and processes that would not normally be called signs. ${ }^{31}$ Now the conception

\footnotetext{
${ }^{27}$ E.g., Peirce 1907b: MS 318, p.176.

${ }^{28}$ See the Index entry common sense in Deely $2001 \mathrm{~b}$.

${ }^{29}$ Peirce 1908: CP 6.464.

${ }^{30}$ Peirce 1908: CP 6.461.

${ }^{31}$ Cf. Peirce 1907b: MS 318:163; Short 1981: 197.
} 
that Peirce takes to be the ordinary, unreflected idea of sign and sign-process is that the activity of signs takes place between human minds, or at least involves an utterer and an interpreter. Such a view may seem to be almost opposite to Peirce's generalised conceptions of sign and semiosis. But in fact Peirce considers this crude idea to contain the seed of truth. He observes that it is highly characteristic of signs that they function on the arena set up by two minds, or 'theatres of consciousness', of which one acts as an utterer and the other as interpreter. ${ }^{32}$ However, he goes on to observe that they are not strictly speaking necessary for the being of signs. That is, he thinks that it is possible that there are sign-relations that do not actively involve utterers and interpreters, although he is not quite certain concerning the interpreter. What is beyond doubt, however, is that the interpretant cannot be simply identified with an interpreter.

Peirce's aim is to abstract those ingredients of utterer and interpreter that are vital to the being of a sign. In other words, he is looking for elements that can virtually perform the significant roles of utterer and interpreter. The ordinary communicative act or interaction is taken as a paradigmatic case of signaction, from which it is possible to extract the core components of the signrelation. Given this assumption, Peirce begins his new derivation of the central components of the sign-relation. (Bergman 2000: 10-11)

"Elements that can virtually perform the significant roles of utterer and interpreter": the sophisticated reader can hardly fail to be struck with the intersemioticity here with the primal text of Poinsot: "it suffices to be a sign virtually in order to signify in act". ${ }^{33}$ And with a single bound, we are back to the original argument advanced in support of the idea of a physiosemiosis, ${ }^{34}$ an action of signs prior to the advent of life on earth, prior to the advent of planets or even stars in the galaxies of Secondness, an action of signs virtually coextensive with the physical domain of Secondness and active therein to make the advent of cognitive and eventually "rational" animals a matter of time, ${ }^{35}$ and therewith both Firstness and Thirdness as semiosis actualized modo explicito and, eventually, thematically, in the birth of the fully semeiotic animal, as I suggest we should see (Deely 2001b: 736-7).

The being of the dinosaur, actually gone, is virtually contained in the petrified bone. And this rock, "transcendentally relative" to its origin in an extinct animal, survives here and now to specify the

${ }^{32}$ Peirce 1907a: EP 2.403.

${ }^{33}$ Poinsot 1632: Book I, Question 1, praecipuum fundamentum, 126/3-4.

34 The original argument traces through Deely 1990, 1991, 1994, 1996, 1998, 1999, 2000, 2001b.

35 an idea that should not come as pure novelty even to those encapsulated in circles centered on the coenoscopic physics and metaphysics of Aristotle and Aquinas, as I once (Deely 1969) took pains to demonstrate. 
awareness of a future observer, who will be called a "paleontologist", as it happens, to form the idea whereby that extinct animal will come to be known, even in its absence, for what it was. The fossil, a "transcendental relation" in the terms of late Latin semiotic, a "representamen" in the semiotic parlance of postmodernity, so exists as to guide the sufficiently knowledgeable observer to an awareness of what once was - not just any observer, mind you; for all we know, it may have been just such a fossil bone perceived only as a suitable rock that David seized for his sling in the slaying of Goliath. The future, it turns out, has more than one way of determining the past in putting it to present use.

Just this indeterminacy is the key to semiosis as the play of relations among objects and things, things and objects, always redrawing the line between what is and what could be, what could be and what will be, and - especially — what will be unforeseeably from a present vantage, for "being can be said in many ways", and which way is determined not by an evolution from past to present alone but by a semiosis wherein the future determines the final outcome of what is now, shaping the past accordingly. For what "is now" determines a range of what it can be taken to be, in a play of interpretants to come; yet which parts of that range, if any (we can be fairly sure there will be some!), will be actualized depends upon chance intersections of causal lines whose very intersection is indetermined in the nature of things. So signs stand to the "present" - any present you please — as objects stand to the past, and interpretants to the future. It - the total Universe made up of the interplay of the three Universes; "being", if you will - appears, exactly as we have become increasingly aware since the 17 th century trial of Galileo, ${ }^{36}$ as one grand unfolding growth wherein the being proper to signs as rooted in the uniqueness of relation as a mode of being cannot but be virtually at play wherever there is interaction among cosmic elements, even down to the "lowest" orders of Brute Secondness.

${ }^{36}$ In the wake of that trial did we all slowly become aware of what Peirce singles out (1908: CP 6.464) and Aquinas anticipated (c.1272/3: II. lect. 17. n. 451, Busa, vol. 4, p. 36) as a choice morsel for musement, "that every small part of space, however remote, is bounded by just such neighbouring parts as every other, without a single exception throughout immensity. The matter of Nature is in every star of the same elementary kinds, and (except for variations of circumstance), what is more wonderful still, throughout the whole visible universe, about the same proportions of the different chemical elements prevail." 
Such is my musement, the hypothesis of physiosemiosis. After all, the threshold from conscious life to vegetable growths ("phytosemiotics $^{, 37}$ ) is a harder threshold speculatively to cross for semioticians than is that thinner boundary between the organic and the inorganic. If biosemiosis be credible, covering phytosemiosis along with zoosemiosis and anthroposemiosis, then a-fortiori physiosemiosis is credible as well, the final frontier in understanding the action of signs. If so, we should not only say, with Sebeok ${ }^{38}$ that semiosis is criterial of life, but of the whole of existence as comprising interacting individuals changing over time and leading to a growth in which consciousness itself appears as an advanced expression, the universe's way of coming to realize that its perfusion with signs may not be the whole of its being but is the whole of the reason its being grows over time. "Symbols grow", Peirce liked to point out, and so star-systems, planets, and ecospheres. And at the heart of all of them is the inexorable play of relations, the root of semiosis, whose trunk is the physical environment, its branches the biosphere, and its leaves the individual organisms with their miniature spiral of guesses, explications, tests, and further guesses, until death resorbs them into that larger process whereby the universe as a whole makes its tentative moves, develops the consequences, modifies them as circumstances warrant, and renews its tentatives, in an even larger spiral of semiosis.

This much seems true, regardless of Peirce's further suggestion ${ }^{39}$ that "in the Pure Play of Musement the idea of God's Reality will be sure sooner or later to be found an attractive fancy, which the Muser will develop in various ways" ${ }^{20}$. For our movement of musement has gone in the other directions, not toward the highest growths of symbolic life but toward the origins of the prior possibility of such a life for finite beings at any level. Our "petite bouchée with the Universes" has taken the form of "considering some connection between two of the three [Firstness and Thirdness], with speculation concerning its cause [the being proper to relation even in the order of Secondness]",

${ }^{37}$ See Krampen 1981; Deely 1987.

${ }^{38}$ E.g., Sebeok 1993.

${ }^{39}$ Peirce 1908: CP 6.465.

40 The semiotician can hardly help to consider the musings of Aquinas and, before him, Augustine concerning the unity of God as consisting in a Triad of Subsisting Relations, personal, communicative, creative, conceivable as such by the finite mind (according to Aquinas c.1266/73: I. 28.) on the very ground in relation that makes finite semioses possible! 
the very kind of musement Peirce ${ }^{41}$ "particularly recommends," although not at all for the particular reason he recommends it. ${ }^{42}$

Yet here we need to go into details, to argue particular cases, such as the formation of mountain ranges, canyons, or the migration of birds, as involving (exactly how?) semiosis. We have reached that point where our "play of musement" requires to be "converted into scientific study". But, as "that cannot be pursued in odd half hours", 43 we must for the nonce leave our physiosemiosis suspended, as it were, between philosophical belief and scientific conviction, confident nonetheless that it will not turn out to be another case of phlogiston, but an essential ingredient or layer in explaining the perfusion of signs through which the universe comes to be as it is and to be known to us insofar as it does.

\section{References}

Aquinas, Thomas i. 1252-1273. S. Thomae Aquinatis Opera Omnia ut sunt in indice thomistico, ed. Roberto Busa. Stuttgart-Bad Cannstatt: FrommannHolzboog, 1980, in septem volumina: 1. In quattuor libros Sententiarum; 2. Summa contra Gentiles, Autographi Deleta, Summa Theologiae; 3. Quaestiones Disputatae, Quaestiones Quodlibetales, Opuscula; 4. Commentaria in Aristotelem et alios; 5. Commentaria in Scripturas; 6. Reportationes, Opuscula dubiae authenticitatis; 7. Aliorum Medii Aevi Auctorum Scripta 61.

- c. 1269/72. Quaestiones Quodlibetales, Quodlibet 4, in Busa ed., vol. 3, 457465.

- c. 1266/73. Summa theologiae, in Busa ed., vol. 2, 184-926.

- c. 1272/3. In libros de coelo et mundo, in Busa ed., vol. 4, 1-49.

Beuchot, Mauricio; Deely, John 1995. Common sources for the Semiotic of Charles Peirce and John Poinsot. Review of Metaphysics 48(3) (March): 539566.

Bergman, Mats 2000. Peirce's derivations of the interpretant. Paper presented in the "Theme Seminar in Philosophical Semiotics" at the University of Helsinki, Fall 2000 semester. [Page references are to the prepublication ms. on which the seminar session was based.]

Deely, John 1969. The philosophical dimensions of the Origin of Species. The Thomist 33 (January and April), Part I: 75-149, Part II: 251-342.

- 1975. Reference to the non-existent. The Thomist 39(2) (April): 253-308.

\footnotetext{
${ }^{41}$ Peirce 1908: CP 6.458.

${ }^{42}$ To wit, because (ibid.) "it will flower in time into the N.A."

${ }^{43}$ Cf. Peirce 1908: CP 6.459.
} 
- 1987. On the notion of phytosemiotics. In: Deely, John; Evans, Jonathan (eds.), Semiotics 1982: 541-554; reprinted with minor revision in Deely; Williams; Kruse 1986: 96-103.

- 1990. Basics of Semiotics. Bloomington: Indiana University Press.

- 1991. Semiotics and biosemiotics: Are sign-science and life-science coextensive? In: Sebeok, Thomas A.; Umiker-Sebeok, Jean (eds.), Biosemiotics. The Semiotic Web 1991. Berlin: Mouton de Gruyter, 1992, 45-75.

- 1994. How does semiosis effect renvoi? The American Journal of Semiotics 11(1/2): 11-61.

- 1994a. The Human Use of Signs; or Elements of Anthroposemiosis. Lanham, MD: Rowman \& Littlefield.

- 1994b. New Beginnings. Early Modern Philosophy and Postmodern Thought. Toronto, Canada: University of Toronto Press.

- 1995. Why investigate the common sources of Charles Peirce and John Poinsot? In: Spinks, C. W; Deely, John (eds.), Semiotics 1994. New York: Peter Lang, 34-50.

- 1996. The grand vision. ${ }^{44}$ In: Colapietro, Vincent M.; Olshewsky, Thomas M. (eds.), Peirce's Doctrine of Signs. Berlin: Mouton de Gruyter, 45-67.

- 1998. How is the universe perfused with signs? In: Spinks, C. W.; Deely, J. N. (eds.), Semiotics 1997. New York: Peter Lang Publishing, Inc., 389-394.

- 1998a. The ethics of terminology. In: Colapetrio, Vincent (ed.), ACPQ Special Issue on Peirce, 72(2): 197-243.

- 1999. Physiosemiosis and semiotics. In: Spinks, C. W.; Deely, J. N. (eds.), Semiotics 1998. New York: Peter Lang, 191-197.

- 2000. A new beginning for the sciences. In: Perron, Paul; Danesi, Marcel; Colilli, Paul; Wattanabee, John (eds.), Semiotics as a Bridge between the Humanities and the Sciences. Ottawa: Legas Press, 95-108.

- 2000a. What Distinguishes Human Understanding? South Bend, St. Augustine's Press.

- 2001a. Umwelt. Semiotica 134 (1/4).

- 2001b. Four Ages of Understanding. The First Postmodern History of Philosophy from Ancient Times to the Turn of the 21th Century. Toronto: University of Toronto Press.

Deely, John N.; Williams, Brooke; Kruse, Felicia E. (eds.). 1986. Frontiers in Semiotics. Bloomington: Indiana University Press.

Eco, Umberto 1990. Unlimited semiosis and rift: Pragmaticism vs. 'pragmatism'. In: The Limits of Interpretation. Bloomington: Indiana University Press, 2343.

\footnotetext{
${ }^{44}$ Presented on September 8 at the September 5-10 1989 Charles Sanders Peirce Sesquicentennial International Congress at Harvard University. This essay was first published in the Transactions of the Charles S. Peirce Society 30(2) (Spring 1994): 371400 , but, inexplicably, after the submission of corrected proofs, the journal repaged the whole and introduced such extreme errors as to make the text unreadable at some points. The correct version has appeared as chapter 7 of Deely 1995: 183-200.
} 
Eco, Umberto; Lambertini, Roberto; Marmo, Costantino; Tabarroni Andrea 1986. Latratus canis or: The dog's barking. In: Deely, Williams \& Kruse 1986: 6373.

Ketner, Kenneth Laine 1981. Peirce's ethics of terminology. Transactions of the Charles S. Peirce Society 17(4): 327-347.

Krampen, Martin 1981. Phytosemiotics. Semiotica 36(3/4): 187-209.

Krempel, A. 1952. La doctrine de la relation chez saint Thomas. Exposé historique et systématique. Paris: J. Vrin.

Maritain, Jacques 1957. Language and the Theory of sign. In: Anschen Ruth Anda (ed.), Language: An Enquiry into Its meaning and Function. New York: Harper and Brothers, 86-101. [Reprinted in Deely, Williams \& Kruse, eds., 1986: 51-62. Page references are based on the 1986 reprint as the most definitive English version.]

Peirce, Charles Sanders ${ }^{45}$ 1865. Lectures "On the Logic of Science", published in W 1.162-302.

- 1867. On a new list of categories. Proceedings of the American Academy of Arts and Sciences 7, 287-298; in CP 1.545-559, with "notes on the preceding" continuing to 1.567; and in W 2.49-59.

- 1868. Some consequence of four incapacities. Journal of Speculative Philosophy 2: 140-157, reprinted in CP 5.264-317.

- 1895. Of reasoning in general. Published in EP 2.11-26.

- c. 1902. From the uncompleted book, Minute Logic, Chapter 1, "Intended Characters of this Treatise", as appearing in CP 2.1-118.

- 1903. The ethics of terminology. In: A Syllabus of Certain Topics of Logic (Boston: Alfred Mudge \& Son), 10-14; reprinted in CP 2.219-2.226 continuing 1.202 .

- 1904. From a letter on 'signs and categories'. Printed in CP 8.327-341.

- 1905-1906. MS 283, partially published under the title "The Basis of Pragmaticism" in CP 1.573-574 (=MS 37-45), 5.549-554 (=MS 45-59), and 5.448n. (=MS 135-148).

- 1907a. Pragmatism. Part of MS 318 published in EP 2.

- 1907b. Pragmatism, MS 318.

${ }^{45}$ CP abbreviates The Collected Papers of Charles Sanders Peirce, Vols. 1-6, Charles Hartshorne and Paul Weiss (eds.); vols. 7-8, Arthur W. Burks (ed.). Cambridge, Mass.: Harvard University Press. The abbreviation followed by volume and paragraph numbers with a period between follows the standard CP reference form.

EP followed by volume and page numbers with a period in between abbreviates the 2-volume set of The Essential Peirce: Selected Philosophical, vol. 1 (1867-1893), vol.2 (1893-1913), eds. N. Houser \& C. Kloesel. Bloomington: Indiana University Press, 1992, 1998, respectively.

$\mathrm{W}$ followed by volume and page numbers with a period in between abbreviates the ongoing Writings of Charles S. Peirce: A Chronological Edition, vols. 1-6, Max H. Fisch et al. (eds.). Bloomington: Indiana University Press, 1982, 1984, 1986, 1989, 1993, 2000 - of a projected 20 published so far.

MS are cited by number, using the pagination made by the Institute for Studies in Pragmaticism at Texas Tech University in Lubbock. 
- 1908. A neglected argument for the reality of God. The Hibbert Journal 7 (October): 90-112; as rerpinted in CP 6.452-485.

- 1909. A Syllabus of Certain Topics of Logic, as partially reprinted in EP 2.

Poinsot, John 1985 [1632]. Tractatus de Signis. The Semiotic of John Poinsot. Berkeley: University of California Press. [References to the volume are by page number, followed by a slash and the appropriate line number of the specific section of text referred to.]

Sebeok, Thomas A. 1993. The sign science and the life science. In: Bernard, Jeff; Deely, John; Voigt, Vilmos; Withalm, Gloria (eds.), Symbolicity. Lanham: University Press of America, 243-252.

Short, Thomas 1981. Semeiosis and intentionality. Transactions of the Charles $S$. Peirce Society 17(3): 197-223.

\section{Физиосемиозис в семиотической спирали: размышление}

Центральным вопросом современной семиотики является вогрос о том, насколько далеко птростирается парадигма знаковых действий, семиозиса. На данный момент существует всеобщее соглашение, что семиозис простирается по менышей мере до пределов сознания или познания, охватывая таким образом и всю область использования знаков животными, т.е. зоосемиозис. Открытым остается вопрос, может ли семиотика быть еще пшие, и тут имеются две точки зрения. Относительно консервативный взгляд распространил бы семиотику на все живое. Такое расширение было впервые предложено и обсуждено под эгидой фитосемиотики, которая является наукой о знаковых процессах на уровне растительной жизни. Это консервативное сообщество сплотилось вокруг биосемиотики. Более радикальное крыло утверждает, что даже такое расширение оставляет нечто за границей, а именно - физический универсум как таковой, от которого зависит и который окружает жизнь в целом. Радикалы считают для знаковых процессов характерным создание образа птрошлого на основе будуших событий. Такое формирование образа можно заметить даже у камней и звезд в небесах - это и есть истинный физиосемиозис, теоретические положения и практические наблюдения которого намечают последний предел семиотического исследования. 


\section{Füsiosemioosis semiootilises spiraalis: mõttejoon}

Keskseks küsimuseks tänapäeva semiootikas on, kui kaugele ulatub märkide toime, semioosise, paradigma. Praeguseks valitseb üldine kokkulepe, et semioosis ulatub vähemalt niikaugele kui teadlikkus või kognitsioon, hõlmates seega terve loomade märgikasutamise ehk zoosemioosise valdkonna. Lahtine on küsimus, kas semiootika võib olla veelgi avaram, ning selles küsimuses on välja kujunenud kaks seisukohta. Suhteliselt konservatiivne seisukoht laiendaks semiootika kõigele elusale. Selline laiendus pakuti esmakordselt välja ja selle üle arutati fütosemiootika sildi all, mis on teadus märgiprotsessidest taimse elu tasandil. Konservatiivid on koondunud biosemiootika ümber. Äärmuslikum seltskond väidab, et isegi selline laiendus jätab midagi välja, nimelt füüsilise universumi tervikuna, millest sõltub ja mis ümbritseb kogu elu. Radikaalide argument peab märgiprotsessidele iseloomulikuks mineviku kujundamist tulevikusündmuste põhjal. Sellist kujundatust võib märgata isegi kivide ja taevatähtede juures - see on tõeline füsiosemioosis, mille teoreetiline õigustus ja praktiline vaatlus märgib semiootilise uurimise viimast piiri. 